\title{
International Unit per Day
}

National Cancer Institute

\section{Source}

National Cancer Institute. International Unit per Day. NCI Thesaurus. Code C85645.

International units per day. 